\title{
Androgenic Hormones Modulate Autoantibody Responses and Improve Survival in Murine Lupus
}

\author{
Jirayr R. Roubinian, Ruben Papoian, and Norman Talal \\ From the Section of Clinical Immunology, Veterans Administration Hospital, and the Department of \\ Medicine, University of California, San Francisco. California 94143
}

A B S TRACT Antibodies to native DNA and to polyadenylic acid (Poly A) occur spontaneously and undergo a regulated switch from IgM to IgG during the course of autoimmune disease in NZB/NZW $F_{1}$ (B/W) mice. B/W females have higher titers and earlier cornmitment to $7 \mathrm{~S}$ antibodies to DNA and Poly A, whereas B/W males bind DNA and Poly A primarily by $19 \mathrm{~S}$ antibodies. We have performed castration experiments to determine the effects of sex hormones on this switch from IgM to IgG.

$\mathrm{NZB} / \mathrm{NZW} \mathrm{F}_{1}(\mathrm{~B} / \mathrm{W})$ mice were either castrated or subjected to sham surgery at $2 \mathrm{wk}$ of age and studied for immunoglobulin class of antibodies to nucleic acids at 4,6 , and 7 mo post-surgery. Prepubertal castration of males caused premature death in $60 \%$ of mice. Castrated males had a significant decline in their serum testosterone concentration, an increase in DNA and Poly A binding, and an accelerated switch from 19S to $7 \mathrm{~S}$ antibodies to nucleic acids. Castrated females had no change in mortality. However, castrated females given maintained androgen treatment had a decreased mortality compared to castrated females receiving estrogen (14 vs. 94\%). The anticipated switch to $7 \mathrm{~S}$ antibodies to Poly $\mathrm{A}$ was almost eliminated in castrated females. These results suggest that sex hormones modulate immunologic regulation and that androgenic hormones are protective in murine lupus.

\section{INTRODUCTION}

Autoimmune diseases in general, and systemic lupus erythematosus $(\mathrm{SLE})^{1}$ in particular, are much more

This work was presented, in part, at the 40th Annual Meeting of the American Rheumatism Association Section of the Arthritis Foundation, Chicago, Ill., June 1976.

Received for publication 20 September 1976 and in revised form 24 February 1977.

${ }^{1}$ Abbreviations used in this paper: B/W, NZB $\times$ NZW $\mathrm{F}_{1}$, hybrid mice; Poly $A$, polyadenylic acid; SLE, systemic lupus erythematosus. common in females than in males (1). An explanation for this clinical difference is not readily apparent. The availability of the NZB/NZW $F_{1}(B / W)$ mouse as a model for SLE has permitted investigation of this question.

B/W mice spontaneously produce LE cells and antibodies to nucleic acids. They develop an immune complex glomerulonephritis associated with the deposition of DNA, immunoglobulin (particularly IgG), and complement (2). Genetic, immunologic, and viral factors are all intimately involved in the pathogenesis of their disorder (3). As in human lupus, there is a striking sex difference in the mouse disease. Female mice have an earlier onset and greater severity of immune complex nephritis compared to males. These pathologic features are associated with an earlier appearance of IgG antibodies to DNA and RNA (4).

We have observed the ordered and sequential appearance of antibodies to DNA and polyadenylic acid (Poly A) in B/W mice (5). As early as 1 mo of age, females bind DNA predominantly by $7 \mathrm{~S}$ IgG antibodies, whereas males bind DNA predominantly by 19S IgM antibodies. As the animals age, antibody titers rise progressively and there is an enhanced formation of $7 \mathrm{~S}$ antibodies to DNA in both sexes. Young mice of both sexes bind Poly A exclusively by 19S antibodies. Females switch to $7 \mathrm{~S}$ antibodies to Poly $\mathrm{A}$ at age $6 \mathrm{mo}$, whereas this switch in males is delayed until 9 mo of age. Thus, the switch to $7 \mathrm{~S}$ antibodies for both DNA and RNA occurs in a regular manner and earlier in female than in male $B / W$ mice.

Neonatal thymectomy causes an initial increase in antibody response to DNA and Poly A, consistent with the removal of thymic suppressor cells (6). It also eliminates the late switch to $7 \mathrm{~S}$ antibodies to Poly A, showing that this response is thymic dependent (6). These results suggest that the ordered sequential appearance of antibodies to nucleic acids in $\mathrm{B} / \mathrm{W}$ mice is, at least in part, related to thymic regulation. 
To study the effect of sex hormones on the spontaneous formation and regulation of antinucleic acid antibodies, we performed prepubertal castration experiments in young $\mathrm{B} / \mathrm{W}$ mice. Our results suggest that both male and female sex hormones influence the titer and immunoglobulin class of antibodies to DNA and RNA. These hormones appear to act on thymic regulatory cells, and the predominant effect is exerted by androgens.

\section{METHODS}

\section{Mice}

B/W mice used in these experiments were derived from our colony at the University of California Vivarium, San Francisco, and were maintained at the Fort Miley Veterans Administration Hospital. Blood was collected from mice at 4,6 , and 7 mo postoperatively by orbital sinus bleeding, allowed to clot at room temperature for $1 \mathrm{~h}$, and left at $4^{\circ} \mathrm{C}$ overnight. Serum was separated by centrifugation at $1,200 \mathrm{~g}$ for $10 \mathrm{~min}$.

\section{Assessment of proteinuria}

Tetrabromphenol paper, (Albustix, Ames Co., Div. of Miles Lab., Inc., Elkhart, Ind.) was used to measure the protein concentration of freshly expressed urine from individual mice.

\section{Operative techniques}

Littermates were randomized and subjected to the surgical procedures or sham operated at $2 \mathrm{wk}$ of age. They were anesthetized by intraperitoneal injection of nembutal.

Oopherectomy. A midline incision was made over the abdomen. Ovaries were identified and removed with electrocautery. The incision was closed with 6-0 silk suture material.

Orchiectomy. Testes were delivered through a scrotal incision. The vas deferens and spermatic vessels were transected with electrocautery, and testes and epididymis were removed. Skin was sutured with 6-0 silk suture material.

Sham operation. In age-matched sham-operated controls, ovaries or testes were identified but left intact.

Experimental animals were distinguished from shamoperated mice by tail clipping. To minimize maternal neglect, the surgical incision and maternal nasal orifices were painted with parlodion-gentian violet solution. No antibiotics were administered at any time.

\section{Hormone replacement}

To achieve a maintained hormone replacement in castrated females, a 2-cm silastic tubing containing 6-7 mg of either estrogen or androgen powder was implanted subcontaneously immediately after the castration procedure. This treatment results in a prompt establishment of an adequate hormone level reached within $12 \mathrm{~h}$, which persists for at least $3 \mathrm{mo}$ (Dr. P. Siiteri, personal communication).
TABLE I

Effect of Castration on Survival in B/W Mice

\begin{tabular}{lccccccccc}
\hline & $\begin{array}{c}\text { No. } \\
\text { of }\end{array}$ & \multicolumn{6}{c}{ Mortality at various ages, (in months) } \\
\cline { 4 - 9 } Procedure & mice & 4 & 6 & 7 & 8 & 9 & 10 & 11 \\
\hline & & & & \multicolumn{6}{c}{$\%$} \\
$\begin{array}{c}\text { Sham } \\
\text { female }\end{array}$ & 14 & 0 & 43 & 64 & 78 & 93 & 100 & \\
$\begin{array}{c}\text { Castrated } \\
\text { female }\end{array}$ & 16 & 0 & 50 & 69 & 87 & 100 & & \\
$\begin{array}{c}\text { Sham } \\
\text { male }\end{array}$ & 12 & 0 & 0 & 0 & 8 & 8 & 8 & 17 \\
$\begin{array}{c}\text { Castrated } \\
\text { male }\end{array}$ & 15 & 0 & $40^{*}$ & $47^{*}$ & $60^{*}$ & $67^{*}$ & $87^{*}$ & $100^{*}$ \\
\hline
\end{tabular}

$* P \leq 0.05$.

\section{Observation}

Mice were observed weekly. Mortality in experimental and control groups was tabulated in $2 \times 2$ contingency tables, and evaluated by Chi square analysis with Yates' modification.

\section{Determination of serum testosterone level}

Serum samples from castrated and sham-operated male mice were pooled separately. Serum testosterone was measured using a radioimmunoassay, described in detail elsewhere (Korenbrot, C., et al. Submitted for publication). An antiserum against testosterone-3-oxime-bovine serum albumin was used. This antiserum had a $70 \%$ crossreactivity with $5 \alpha$-dihydrotestosterone. Since no purification step was used beyond diethyl-ether extraction of the serum samples, the values given for testosterone are slightly contaminated with circulating dihydrotestosterone. This assay was kindly performed by Dr. I. Huataniemi in the Reproductive Research Laboratory of Dr. P. Siiteri.

\section{Fractionation of serum}

Serum samples from castrated and sham-operated mice were pooled separately. $200 \mu \mathrm{l}$ of pooled serum samples was subjected to ultracentrifugation in a $10-35 \%$ sucrose density gradient $(0.15 \mathrm{M} \mathrm{NaCl}, \mathrm{pH} 8.0)$ as previously described (7). Bovine thyroglobulin (19S), human gamma globulin (7S), and hemoglobin (4S) were used as sedimentation markers. 40 fractions were collected and each was analyzed for antibody to DNA and Poly A. Peak fractions were tested for immunoglobulin content. In the $19 \mathrm{~S}$ region (fraction 10-20) only activity against $\mu$-chains could be detected by Ouchterlony analysis, while in the $7 \mathrm{~S}$ region (fractions 20-30) activity against $\gamma$-chains, but not $\mu$-chains, was present.

\section{Anti-DNA and anti-RNA assays}

Antibodies to DNA and Poly A were determined separately with a cellulose ester filter radioimmunoassay. The radioactive nucleic acids were double-stranded DNA ( $\left.\left[{ }^{3} \mathrm{H}\right] \mathrm{DNA}\right)$ from KB cells (obtained from Electro-Nucleonics Laboratories, Bethesda, Md.), and $\left[{ }^{3} \mathrm{H}\right]$ polyriboadenylic acid (Miles Laboratories Inc., Miles Research Products, Elkhart, 
TABLE II

Serum Testosterone Concentration of Male B/W Mice

\begin{tabular}{ccc}
\hline \multirow{2}{*}{ Age of mice } & \multicolumn{2}{c}{ Operative procedure } \\
\cline { 2 - 3 } & Sham & Castrated \\
\hline mo & \multicolumn{3}{c}{$n g / m l$} \\
4 & 5.77 & 0.92 \\
6 & 4.63 & 0.67 \\
7 & 4.71 & 0.69 \\
\hline
\end{tabular}

Ind.). The radioactive antigens were incubated with decomplemented $50-\mu \mathrm{l}$ aliquots of each fraction for $30 \mathrm{~min}$ at $37^{\circ} \mathrm{C}$ followed by an overnight incubation at $4^{\circ} \mathrm{C}$. The antigen-antibody complexes were collected onto cellulose ester filters (Millipore Corp., Bedford, Mass.). The filters were placed in counting vials and covered with $10 \mathrm{ml}$ of Liquofluour-toluene scintillation medium. Radioactivity was determined in a Packard liquid scintillation counter (Packard Instrument Co., Downers Grove, Ill.) The results are expressed as corrected counts per minute retained on the filter, a value which is directly related to serum antibody concentration (8). To determine the specificity of binding, monospecific rabbit anti-mouse $\mu$-chains and antimouse $\gamma$-chains were added to peak fractions from the 19S and $7 \mathrm{~S}$ regions respectively. Anti- $\mu$ inhibited DNA binding between $77-100 \%$, while anti- $\gamma$ inhibited binding between $66-78 \%$. Addition of goat anti-mouse albumin to these gradient fractions had no inhibitory effect.

\section{Calculation of 7S:19S antibody binding}

The radioactive binding profiles revealed clear distribution into $7 \mathrm{~S}$ and $19 \mathrm{~S}$ peaks of activity after sucrose gradient fractionation. The radioactivity representing the fractionated 7S and 19S peaks within a single gradient were added and compared for total binding activity, which gave a result generally comparable to results with unfractionated whole serum.

\section{Measurement of immunoglobulin concentration}

A single radial immunodiffusion method (9) was used to determine immunoglobulin concentration. Determinations were made of $\operatorname{IgM}, \operatorname{IgG}_{1}$, and $\operatorname{IgG}_{2}$ with pooled sera from sham-operated and castrated $B / W$ male and female mice. No significant difference in immunoglobulin concentrations was found.

\section{RESULTS}

Effects of castration on survival of $B / W$ mice. Castration did not affect the life span of female B/W mice, but it increased the mortality of male B/W mice starting at 6 mo of age (Table I). By 11 mo of age, all of the castrated male mice were dead compared to only 2 of 12 sham-operated male controls. Mortality of castrated male $\mathrm{B} / \mathrm{W}$ mice was not statistically different from that of sham-operated or castrated female $\mathrm{B} / \mathrm{W}$ mice.

Effects of castration on serum testosterone concen- tration of male $B / W$ mice. Castration caused a significant decline in the concentration of serum testosterone in male $\mathrm{B} / \mathrm{W}$ mice. Testosterone levels of castrated males measured at 4,6 , and 7 mo were onesixth that of sham-operated male B/W mice (Table II).

Development of antibodies to DNA and Poly A in castrated female $B / W$ mice. At 4 mo of age, sham-operated female B/W mice had both $19 \mathrm{~S}$ and 7S antibodies to DNA, with the latter predominating (Table III). Binding of DNA by $7 \mathrm{~S}$ antibodies became even more pronounced at 6 and 7 mo (Table III). Antibodies to Poly A were exclusively 19S at $4 \mathrm{mo}$, but switched to primarily $7 \mathrm{~S}$ antibodies at $6 \mathrm{mo}$. This pattern was maintained at $7 \mathrm{mo}$ (Table III).

Prepubertal castration caused a slight decrease in the magnitude of the anti-DNA response at 4 mo, but had no effect at 6 mo (Table III). At $7 \mathrm{mo}$, there was less 7S binding of DNA in castrated females, while the 195 binding was unaffected (Table III).

Poly A binding remained almost exclusively $19 \mathrm{~S}$ post-castration. The expected $7 \mathrm{~S}$ response to Poly A was markedly reduced at 6 mo and virtually absent at 7 mo (Table III). By contrast, the $19 \mathrm{~S}$ response at these ages was almost unchanged.

Development of antibodies to DNA and Poly A in castrated male $B / W$ mice. Antibodies to DNA in sham-operated male $\mathrm{B} / \mathrm{W}$ mice were less than in females and predominantly 19S (Table IV). The switch to $7 \mathrm{~S}$ antibodies to DNA occurred at $7 \mathrm{mo}$ of age. Some 7S antibodies to Poly $A$ appeared at 7 mo (Table IV). The results in sham-operated males and females were generally comparable to data obtained previously in control, nonoperated $\mathrm{B} / \mathrm{W}$ mice $(5,6)$. The decrease in DNA binding in sham-operated males between 4 and 6 mo may be due to the formation of immune complexes, as noted previously (5).

Prepubertal castration caused a proportionate in-

TABLE III

Total Radioactivity Representing Fractionated 7S and 19S Peaks in NZB/NZW F Female Mice

\begin{tabular}{rlrrrrr}
\hline & & \multicolumn{2}{c}{ DNA } & & \multicolumn{2}{c}{ Poly A } \\
\cline { 7 - 7 } Age & Procedure & \multicolumn{1}{c}{195} & $7 \mathrm{~S}$ & & 195 & $7 \mathrm{~s}$ \\
\hline$m o$ & & & & & & \\
4 & Sham & 993 & 1,314 & & 439 & 0 \\
& Castrated & 740 & 872 & & 292 & 0 \\
6 & Sham & 348 & 1,449 & & 1,004 & 1,326 \\
& Castrated & 351 & 1,467 & & 1,096 & 133 \\
7 & Sham & 1,327 & 3,702 & & 781 & 2,050 \\
& Castrated & 1,294 & 2,271 & & 585 & 37 \\
\hline
\end{tabular}


crease in both 19S and 7S antibodies to DNA at 4 mo of age (Table IV). At $6 \mathrm{mo}$, castrated males showed an accelerated switch to $7 \mathrm{~S}$ anti-DNA antibodies, resembling females in titer and immunoglobulin class. Markedly increased binding of DNA persisted at $7 \mathrm{mo}$ (Table IV). These results are similar to the effects of neonatal thymectomy in male $\mathrm{B} / \mathrm{W}$ mice (6).

Antibodies to Poly A were only slightly increased at the 4th mo post-castration. At $6 \mathrm{mo}$, there was an accelerated appearance of $7 \mathrm{~S}$ anti-Poly $\mathrm{A}$ antibodies. This premature switch to $7 \mathrm{~S}$ response to Poly A was quite marked at $7 \mathrm{mo}$, with castrated males again resembling females in this respect (Table IV).

Effects of sex hormone replacement on disease in castrated female B/W mice. Castrated female B/W mice were given subcutaneous implants containing either estrogen or androgen. Animals replaced with estrogen had a $94 \%$ mortality at $8 \mathrm{mo}$, compared to $14 \%$ in the female mice receiving androgen (Table V). The estrogen-treated mice had larger amounts of both $19 \mathrm{~S}$ and $7 \mathrm{~S}$ antibodies to DNA and Poly A when compared to the androgentreated mice. The most striking difference was in the $7 \mathrm{~S}$ response to Poly $\mathrm{A}$, which was greatly reduced in the mice receiving androgen (Table $\mathrm{V}$ ). Proteinuria ranged between 100 and $1,000 \mathrm{mg} /$ $100 \mathrm{ml}$ in mice replaced with estrogen, and was less than $100 \mathrm{mg} / 100 \mathrm{ml}$ in mice receiving androgen. In preliminary experiments, the kidneys of estrogentreated mice showed marked lymphocytic infiltration and glomerulonephritis, whereas the kidneys in animals receiving androgen showed minimal lymphocytic infiltration and glomerular changes.

\section{DISCUSSION}

The greater severity of autoimmune disease in female B/W mice (compared to males) seems es-

TABLE IV

Total Radioactivity Representing Fractionated 7S and 19S Peaks in NZB/NZW $F_{1}$ Male Mice

\begin{tabular}{llrrrrr}
\hline & & \multicolumn{2}{c}{ DNA } & & \multicolumn{2}{c}{ Poly A } \\
\cline { 7 - 8 } \cline { 7 - 7 } Age & Procedure & \multicolumn{1}{c}{$19 \mathrm{~S}$} & $7 \mathrm{~S}$ & & $19 \mathrm{~S}$ & $7 \mathrm{~S}$ \\
\hline$m o$ & & & & & \\
4 & Sham & 615 & 324 & & 186 & 0 \\
& Castrated & 1,200 & 881 & & 280 & 0 \\
6 & Sham & 136 & 83 & & 815 & 85 \\
& Castrated & 593 & 1,336 & & 722 & 267 \\
7 & Sham & 211 & 788 & & 324 & 137 \\
& Castrated & 1,026 & 2,488 & & 928 & 1,304 \\
\hline
\end{tabular}

TABLE V

Effects of Castration and Hormone Replacement on Survival and Autoantibody Responses in Female B/W Mice

\begin{tabular}{|c|c|c|c|c|c|}
\hline \multirow[b]{3}{*}{ Procedure } & \multirow{3}{*}{$\begin{array}{l}\text { Mortality } \\
\text { at } 8 \mathrm{mo}^{*}\end{array}$} & \multicolumn{4}{|c|}{$\begin{array}{l}\text { Anti-nucleic acid antibody } \\
\text { responses at } 7 \mathrm{mot}\end{array}$} \\
\hline & & \multicolumn{2}{|c|}{ DNA } & \multicolumn{2}{|c|}{ Poly A } \\
\hline & & $19 S$ & $7 \mathrm{~S}$ & $19 S$ & $7 \mathrm{~S}$ \\
\hline & $\%$ & & & & \\
\hline $\begin{array}{l}\text { Castrated female } \\
\text { receiving estro- } \\
\text { gen implant }\end{array}$ & $94(16 / 17)$ & 1,552 & 2,583 & 2,138 & 2,427 \\
\hline $\begin{array}{l}\text { Castrated female } \\
\text { receiving andro- } \\
\text { gen implant }\end{array}$ & $14(2 / 14) \S$ & 1,314 & 1,878 & 1,139 & 275 \\
\hline
\end{tabular}

* Number of mice dead/total number of mice.

\$ Total radioactivity representing fractionated $7 \mathrm{~S}$ and $19 \mathrm{~S}$ peaks.

$\$ P \leq 0.05$.

tablished very early in life, perhaps even at birth. There is more anti-DNA antibody formation in these female mice associated with an earlier switch to 7S antibody and accelerated appearance of severe lupus nephritis.

We undertook this study to determine whether sex hormones influenced the disease expression in B/W mice, and if so, whether the predominant effect could be attributed to male or female hormones. In a previous study, Steinberg et al. (10) observed that castration of male $\mathrm{B} / \mathrm{W}$ mice at $5 \mathrm{wk}$ produced a slight increase in DNA binding at $6 \frac{1}{2}$ mo of age. In the present study, we have obtained evidence that androgens may play a major protective role.

The alteration in hormone status as a result of prepubertal castration was shown by the marked decline in serum testosterone concentration. These castrated males developed a disease pattern that resembled sham-operated females, associated with an increase in DNA and RNA binding, and an accelerated switch to $7 \mathrm{~S}$ antibodies. 9 of 15 castrated males were dead prematurely by 8 mo of age.

By contrast, prepubertal castration of female $\mathrm{B} / \mathrm{W}$ mice had no effect on life span and less effect on anti-nucleic acid antibodies. The only change in the DNA response was a modest decrease in $7 \mathrm{~S}$ antibodies observed at 7 mo. However, there was a striking effect on the Poly A response. The anticipated switch to $7 \mathrm{~S}$ antibodies was virtually eliminated by prepubertal castration, whereas the 19S antibodies were unaffected.

The results of our castration experiments are consistent with the known effects of androgens and estrogens on the normal immune response. Immune 
reactivity is generally enhanced in females compared to males (11). Females have higher immunoglobulin concentrations, make greater primary and secondary antibody responses, are more resistant to the induction of immunologic tolerance, have an enhanced capacity for cell mediated immunity, are more effective in the rejection of tumors and homografts, and have enhanced responses in mixed lymphocyte culture. Eidinger and Garrett observed that castration or thymectomy each resulted in an enhanced response to polyvinylpyrrolidone in male mice (12). However, combined castration and thymectomy abolished the expected enhancement of antibody formation seen after gonadectomy alone. These results suggest that androgens exert their effect at the level of thymocytes, and that the presence of the thymus is required to demonstrate the effect of orchiectomy.

Immunologic processes localized in the thymus, therefore, seem highly sensitive to regulation by sex hormones. Our findings suggest that autoantibody responses may also be sensitive to hormonal modulation, and possibly by mechanisms involving thymocytes. Neonatal thymectomy of male $B / W$ mice resulted in changes in anti-DNA antibodies similar to those seen in castrated male mice (6). There was a rapid and persistent increase in $19 \mathrm{~S}$ and $7 \mathrm{~S}$ anti-DNA antibodies which was followed by an accelerated switch to predominantly $7 \mathrm{~S}$ antibodies. Moreover, neonatal thymectomy in both male and female B/W mice virtually abolished the late switch to $7 \mathrm{~S}$ antibodies to Poly $\mathrm{A}$, suggesting a thymic requirement for this differentiation event.

Antibodies to DNA in female $\mathrm{B} / \mathrm{W}$ mice are distinguished from anti-DNA in males and from anti-Poly $A$ in both sexes by virtue of their relative resistance to the effects of either castration or thymectomy. This could relate to a premature extra-thymic peripheralization of the anti-DNA response in females so that it becomes independent of the thymus during neonatal life. The Poly A response in females, and both DNA and Poly A responses in males, may become peripheralized more slowly and are therefore more susceptible to hormonal manipulation.

The opposite effect on the 7S response to Poly $A$ induced by castration of male and female mice is striking. Castrated males develop an accelerated switch to $7 \mathrm{~S}$, whereas in the castrated females this response is abrogated. We interpret these results as reflecting an alteration in the equilibrium between helper and suppressor influences as a result of hormonal modulation. Castrated males may be deficient in suppressor regulation, whereas castrated females may lack a helper influence necessary for the full development of a 7S response to Poly A.

Our experiments offer an explanation for the greater incidence of lupus and other autoimmune diseases in females compared to males. They further suggest that autoimmunity may arise as a consequence of disordered immunologic regulation in which physiologic control mechanisms are still operative, albeit in a defective manner. The improved survival and disease manifestations in castrated female mice given androgen suggests that hormonal modulation of murine lupus may have important therapeutic possibilities. The preliminary observations are currently being investigated in a large study involving both castrated male and female mice given the same or opposite sex hormone, as well as mice subjected to androgen therapy during the course of established disease.

\section{ACKNOWLEDGMENTS}

This investigation was supported by grant AM 16140 from the U. S. Public Health Service and by research funds from the Veterans Administration.

\section{REFERENCES}

1. Dubois, E. L., editor. 1974. Lupus Erythematosus. University of Southern California Press, Los Angeles, Calif.

2. Howie, J. B., and B. J. Helyer. 1968. The immunology and pathology of NZB mice. Adv. Immunol. 9: 215-266.

3. Talal, N. 1970. Immunologic and viral factors in the pathogenesis of systemic lupus erythematosus. Arthritis Rheum. 13: 887-894.

4. Lambert, P. H., and F. J. Dixon. 1968. Pathogenesis of the glomerulonephritis of NZB/W mice. J. Exp. Med. 127: 507-522 (and plates 63-68).

5. Papoian, R., R. Pillarisetty, and N. Talal. 1977. Immunologic regulation of spontaneous antibodies to DNA and RNA. II. Sequential switch from IgM to IgG in NZB/NZW F $F_{1}$ mice. Immunology. 32: 75-79.

6. Roubinian, J. R., R. Papoian, and N. Talal. 1977. Effects of neonatal thymectomy and splenectomy on survival and regulation of autoantibody formation in $\mathrm{NZB} / \mathrm{NZW} \mathrm{F}_{1}$ mice J. Immunol. In press.

7. Talal, N., and R. Pillarisetty. 1975. IgM and IgG antibodies to DNA, RNA, and DNA:RNA in systemic lupus erythematosus. Clin. Immunol. Immunopathol. 4: 24-31.

8. Attias, M. R., R. A. Sylvester, and N. Talal. 1973. Filter radioimmunoassay for antibodies to reovirus RNA in systemic lupus erythematosus. Arthritis Rheum. 16: 719-725.

9. Mancini, G., A. O. Carbonara, and J. F. Heremans. 1965. Immunochemical quantitation of antigens by single radial immunodiffusion. Immunochemistry. 2: 235-254.

10. Steinberg, A. D., T. Pincus, and N. Talal. 1971. The pathogenesis of autoimmunity in New Zealand mice. III. Factors influencing the formation of anti-nucleic acid antibodies. Immunology. 20: 523-531.

11. Terres, G., S. L. Morrison, and G. S. Habicht. 1968. A quantitative difference in the immune response between male and female mice. Proc. Soc. Exp. Biol. Med. 127: 664-667.

12. Eidinger, D., and T. J. Garrett. 1972. Studies of the regulatory effects of the sex hormones on antibody formation and stem cell differentiation. J. Exp. Med. 136: $1098-1116$. 